\title{
Ilościowe i jakościowe problemy zamówień publicznych w procesie inwestycyjno-budowlanym
}

\author{
Andrzej Borowicz \\ Prof. dr hab. Uniwersytet Łódzki, Wydział Ekonomiczno- \\ -Socjologiczny, Katedra Inwestycji i Nieruchomości \\ http://dx.doi.org/10.18778/8088-114-3.11
}

$\mathrm{W}$ procesie inwestycyjno-budowlanym, oprócz zamówień na wykonanie robót budowlanych, występuje szereg innych rodzajów zamówień publicznych. Wśród nich szczególnie istotne znaczenie mają zamówienia na:

- dokumentację urbanistyczną (studia uwarunkowań i kierunków zagospodarowania przestrzennego oraz miejscowe plany zagospodarowania przestrzennego),

- dokumentację projektową (projekty budowlane, projekty wykonawcze, przedmiary robót, wytyczne do sporządzenia planu bezpieczeństwa i ochrony zdrowia na placu budowy, programy funkcjonalno-użytkowe),

- sprawowanie nadzoru inwestorskiego,

- pełnienie funkcji inwestora zastępczego oraz

- zaprojektowanie i wykonanie robót budowlanych według wytycznych do projektowania (PFU) dostarczonych przez inwestora.

Efektywne udzielenie tych zamówień w sposób oczywisty wpływa na sprawność procesów inwestycyjno-budowlanych w polskim sektorze publicznym. Przez wielu pojęcia te są nawet (mylnie) utożsamiane. W ostatnich latach $\mathrm{w}$ przebiegu procesów inwestycyjno-budowlanych w polskim sektorze publicznym ujawniło się wiele nieprawidłowości. Za ich wystąpienie, w sposób uproszczony i nie do końca uprawniony, zaczęto winić system zamówień publicznych. Tymczasem faktem jest, że choć system zamówień publicznych ma swoje specyficzne problemy, to jednak nie są one $\mathrm{w}$ pełni tożsame z przyczynami niedostatecznej efektywności inwestowania budowlanego w polskim sektorze publicznym. Lista tych ostatnich zdecydowanie wykracza poza listę niesprawności polskiego systemu zamówień publicznych.

W sytuacji opisanej powyżej, celem niniejszej publikacji jest udokumentowane omówienie kilku wybranych, naszym zdaniem jednak szczególnie 
istotnych, problemów ilościowych oraz jakościowych zamówień publicznych udzielanych w procesach inwestycyjno-budowlanych.

Tłem oraz kanwą merytoryczną dla tych problemów jest statystyczna charakterystyka przedmiotowych rynków zamówień publicznych, którą prezentujemy poniżej.

\section{Problemy sygnalizowane przez statystyczną charakterystykę budowlanych}

\subsection{Strona popytowa rynków}

Stronę popytową rynków zamówień publicznych będących przedmiotem wnioskowania poddano analizie na podstawie ogłoszeń o wszczęciu postępowań opublikowanych w Biuletynie Zamówień Publicznych (BZP) w latach 2000-2015 (I-III). Rozmiary tych rynków, określone na podstawie ogólnej liczby ogłoszeń o wszczęciu postępowania, zaprezentowano w tabeli 1 i na wykresie 1.

Najistotniejszy wniosek, jaki można sformułować na podstawie danych przedstawionych $\mathrm{w}$ tabeli 1 i na wykresie 1 , mówi o istotnej zależności pomiędzy dynamiką rozwojową poszczególnych rynków a dopływem środków finansowych pochodzących budżetu UE. Zależność ta szczególnie wyraźnie występowała na rynku zamówień publicznych na dokumentację urbanistyczną, projektową oraz zastępstwo inwestycyjne.

Tak istotna kumulacja zamówień, wyrażająca się w zwielokrotnionej ilości przetargów w pierwszych latach unijnej perspektywy finansowej, musi wpłynąć negatywnie zarówno na zachowania konkurencyjne (w tym cenotwórcze) uczestników przetargów jak i na wyniki poszczególnych postępowań przetargowych.

\begin{tabular}{|c|c|c|c|c|c|c|}
\hline \multirow{2}{*}{ Rok } & \multicolumn{2}{|c|}{$\begin{array}{c}\text { Zamówienia } \\
\text { na dokumentację }\end{array}$} & \multicolumn{2}{c|}{$\begin{array}{c}\text { Zamówienia } \\
\text { na usługi inżynierskie }\end{array}$} & \multicolumn{2}{|c|}{$\begin{array}{c}\text { Zamówienia } \\
\text { na roboty budowlane }\end{array}$} \\
\cline { 2 - 7 } & $\begin{array}{c}\text { Dokumenta- } \\
\text { cja urbani- } \\
\text { styczna }\end{array}$ & $\begin{array}{c}\text { Dokumen- } \\
\text { tacja } \\
\text { projektowa }\end{array}$ & $\begin{array}{c}\text { Nadzór } \\
\text { inwestorski }\end{array}$ & $\begin{array}{c}\text { Zastępstwo } \\
\text { inwestycyjne }\end{array}$ & $\begin{array}{c}\text { Wykonanie } \\
\text { robót bu- } \\
\text { dowlanych } \\
\text { wanie } \\
\text { i wykonanie } \\
\text { robót bu- } \\
\text { dowlanych }\end{array}$ \\
\hline 1 & 2 & 3 & 4 & 5 & 6 & 7 \\
\hline 2000 & 160 & 805 & 59 & 52 & 17318 & 281 \\
\hline 2001 & 190 & 775 & 44 & 55 & 17781 & 569 \\
\hline
\end{tabular}




\begin{tabular}{|c|c|c|c|c|c|c|}
\hline 1 & 2 & 3 & 4 & 5 & 6 & 7 \\
\hline 2002 & 138 & 614 & 54 & 29 & 18355 & 510 \\
\hline 2003 & 193 & 845 & 50 & 13 & 15712 & 418 \\
\hline 2004 & 52 & 643 & 58 & 9 & 11744 & 236 \\
\hline 2005 & 46 & 626 & 62 & 18 & 11821 & 379 \\
\hline 2006 & 48 & 654 & 39 & 22 & 17143 & 412 \\
\hline 2007 & 326 & 4003 & 188 & 43 & 35728 & 845 \\
\hline 2008 & 563 & 5461 & 495 & 71 & 53318 & 1125 \\
\hline 2009 & 552 & 688 & 1283 & 104 & 52690 & 804 \\
\hline 2010 & 402 & 253 & 1568 & 98 & 51685 & 943 \\
\hline 2011 & 406 & 223 & 1085 & 75 & 45194 & 938 \\
\hline 2012 & 409 & 160 & 1045 & 56 & 44676 & 890 \\
\hline 2013 & 285 & 139 & 957 & 38 & 39667 & 730 \\
\hline 2014 & 197 & 68 & 840 & 58 & 43171 & 851 \\
\hline 2015 & 27 & 12 & 102 & 1 & 5805 & 131 \\
\hline$(I-I I I)$ & & & & & & \\
\hline
\end{tabular}

Tabela 1. Zamówienia publiczne w procesie inwestycyjno-budowlanym wszczynane w latach 2000-2015 (I-III) Źródło: obliczenia własne na podstawie BZP.

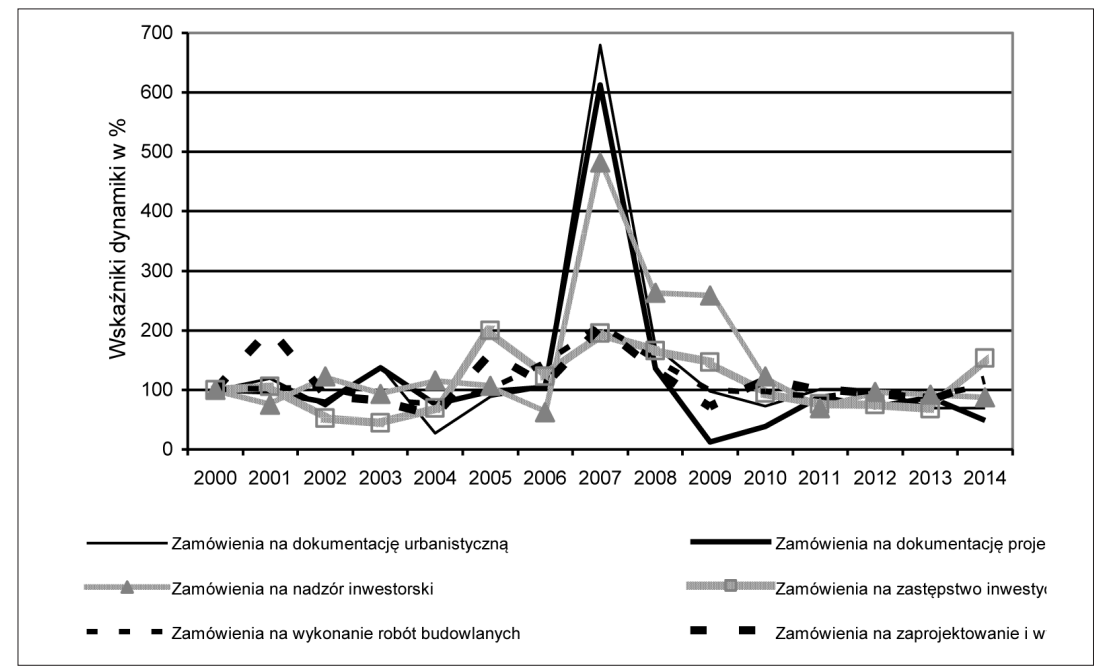

Wykres 1. Zamówienia publiczne w procesie inwestycyjno-budowlanym wszczynane w latach 2000-2014 - wizualizacja tendencji Źródło: opracowanie własne na podstawie tabeli 1.

Dodatkowo, nadmierna amplituda wahań popytu efektywnego na większości badanych rynków powodować musi okresowe problemy z wykorzystaniem mocy produkcyjnych lub usługowych u tych wykonawców, dla których zamówienia publiczne są istotnym lub dominującym elementem portfela zleceń. 


\subsection{Strona podażowa rynków}

W przypadku strony podażowej analizowanych rynków informacje źródłowe, jakie można było uzyskać na podstawie ogłoszeń o udzieleniu zamówień publicznych w BZP, pozwoliły na dokonanie analizy takich problemów jak:

- ogólna intensywność konkurencji na badanych rynkach zamówień publicznych wyrażona średnią liczbą ofert złożonych w danym postępowaniu oraz

- intensywność konkurencji cenowej wyrażona wskaźnikiem zróżnicowania oferowanych cen $W_{z}$.

Dane liczbowe pozwalające na przeprowadzenie analiz o których mowa, zaprezentowano $\mathrm{w}$ tabeli 2 i na wykresie 2 i 3.

\begin{tabular}{|c|c|c|c|c|c|c|}
\hline \multirow[b]{2}{*}{ Rok } & \multicolumn{2}{|c|}{$\begin{array}{c}\text { Zamówienia } \\
\text { na dokumentację }\end{array}$} & \multicolumn{2}{|c|}{$\begin{array}{c}\text { Zamówienia } \\
\text { na usługi inżynierskie }\end{array}$} & \multicolumn{2}{|c|}{$\begin{array}{c}\text { Zamówienia } \\
\text { na roboty budowlane }\end{array}$} \\
\hline & $\begin{array}{c}\text { Dokumenta- } \\
\text { cja urbani- } \\
\text { styczna }\end{array}$ & $\begin{array}{c}\text { Dokumenta- } \\
\text { cja projek- } \\
\text { towa }\end{array}$ & $\begin{array}{l}\text { Nadzory } \\
\text { inwestor- } \\
\text { skie }\end{array}$ & $\begin{array}{l}\text { Zastęp- } \\
\text { stwo inwe- } \\
\text { stycyjne }\end{array}$ & $\begin{array}{l}\text { Wykonanie } \\
\text { robót bu- } \\
\text { dowlanych }\end{array}$ & $\begin{array}{c}\text { Zaprojektowanie } \\
\text { i wykonanie robót } \\
\text { budowlanych }\end{array}$ \\
\hline 1 & 2 & 3 & 4 & 5 & 6 & 7 \\
\hline \multicolumn{7}{|c|}{ A. Średnia ilość ofert na 1 postępowanie } \\
\hline 2000 & 3,63 & 4,90 & 4,03 & 5,25 & 5,05 & 3,93 \\
\hline 2001 & 4,48 & 5,49 & 3,41 & 5,31 & 5,35 & 4,03 \\
\hline 2002 & 5,18 & 5,14 & 3,34 & 4,53 & 4,75 & 3,69 \\
\hline 2003 & 4,46 & 4,53 & 2,92 & 3,53 & 4,70 & 4,08 \\
\hline 2004 & 3,35 & 3,22 & 2,46 & 2,17 & 3,99 & 3,10 \\
\hline 2005 & 1,66 & 2,99 & 2,84 & 2,94 & 3,48 & 2,47 \\
\hline 2006 & 2,22 & 2,70 & 2,69 & 2,08 & 2,99 & 2,51 \\
\hline 2007 & 2,74 & 2,23 & 2,31 & 2,69 & 2,55 & 2,00 \\
\hline 2008 & 2,84 & 2,40 & 2,67 & 2,20 & 3,05 & 2,24 \\
\hline 2009 & 3,58 & 4,04 & 3,03 & 2,66 & 4,16 & 3,33 \\
\hline 2010 & 4,61 & 6,01 & 2,81 & 2,45 & 3,81 & 3,20 \\
\hline 2011 & 6,03 & 7,48 & 3,60 & 4,34 & 3,83 & 3,35 \\
\hline 2012 & 5,75 & 6,78 & 3,98 & 3,70 & 4,68 & 3,46 \\
\hline 2013 & 5,12 & 5,41 & 4,18 & 2,95 & 4,20 & 3,35 \\
\hline 2014 & 5,09 & 5,29 & 3,77 & 3,45 & 3,90 & 3,20 \\
\hline $\begin{array}{l}2015 \\
(I-I I I)\end{array}$ & 2,78 & 5,45 & 4,46 & 4,00 & 5,32 & 3,70 \\
\hline \multicolumn{7}{|c|}{ Wskaźniki zróżnicowania cen ofertowych ${ }^{\star}$} \\
\hline 2000 & 2,00 & 2,46 & 1,98 & 2,89 & 1,43 & 1,70 \\
\hline 2001 & 2,44 & 2,59 & 2,34 & 3,10 & 1,42 & 1,63 \\
\hline 2002 & 2,64 & 2,61 & 1,72 & 3,83 & 1,43 & 1,66 \\
\hline
\end{tabular}




\begin{tabular}{|c|c|c|c|c|c|c|}
\hline 1 & 2 & 3 & 4 & 5 & 6 & 7 \\
\hline 2003 & 2,23 & 2,38 & 1,80 & 2,31 & 1,39 & 1,72 \\
\hline 2004 & 1,98 & 1,93 & 1,76 & 3,25 & 1,33 & 1,36 \\
\hline 2005 & 2,32 & 1,78 & 3,27 & 2,25 & 1,28 & 1,57 \\
\hline 2006 & 1,56 & 1,79 & 1,71 & 1,20 & 1,27 & 1,27 \\
\hline 2007 & 1,68 & 1,66 & 1,65 & 1,83 & 1,28 & 1,26 \\
\hline 2008 & 1,66 & 1,67 & 1,88 & 1,35 & 1,35 & 1,54 \\
\hline 2009 & 2,05 & 2,24 & 2,19 & 1,91 & 1,42 & 1,64 \\
\hline 2010 & 2,44 & 3,03 & 2,25 & 1,97 & 1,41 & 1,61 \\
\hline 2011 & 2,65 & 3,33 & 3,14 & 2,84 & 1,55 & 2,06 \\
\hline 2012 & 2,87 & 3,16 & 3,44 & 2,40 & 1,62 & 1,91 \\
\hline 2013 & 3,28 & 2,96 & 3,71 & 3,07 & 1,58 & 2,05 \\
\hline 2014 & 3,01 & 2,76 & 3,40 & 3,30 & 1,57 & 1,83 \\
\hline 2015 & 2,37 & 2,28 & 4,07 & 2,28 & 1,82 & 1,96 \\
\hline (I-III) & & & & & & \\
\hline
\end{tabular}

Tabela 2. Intensywność konkurencji na badanych rynkach zamówień publicznych w latach 2000-2015 (I-III)

*) Wskaźniki zróżnicowania cen ofertowych przedstawione w tabeli obliczono według wzoru a) $W_{z}=\frac{\sum_{i=1}^{n} \frac{C_{\max }}{C_{\min }}}{n}$, gdzie: $C_{\max }, C_{\min }=$ najwyższa i najniższa cena $w$ danym postępowaniu, $n=$ liczba badanych postępowań Źródło: obliczenia własne na podstawie BZP.

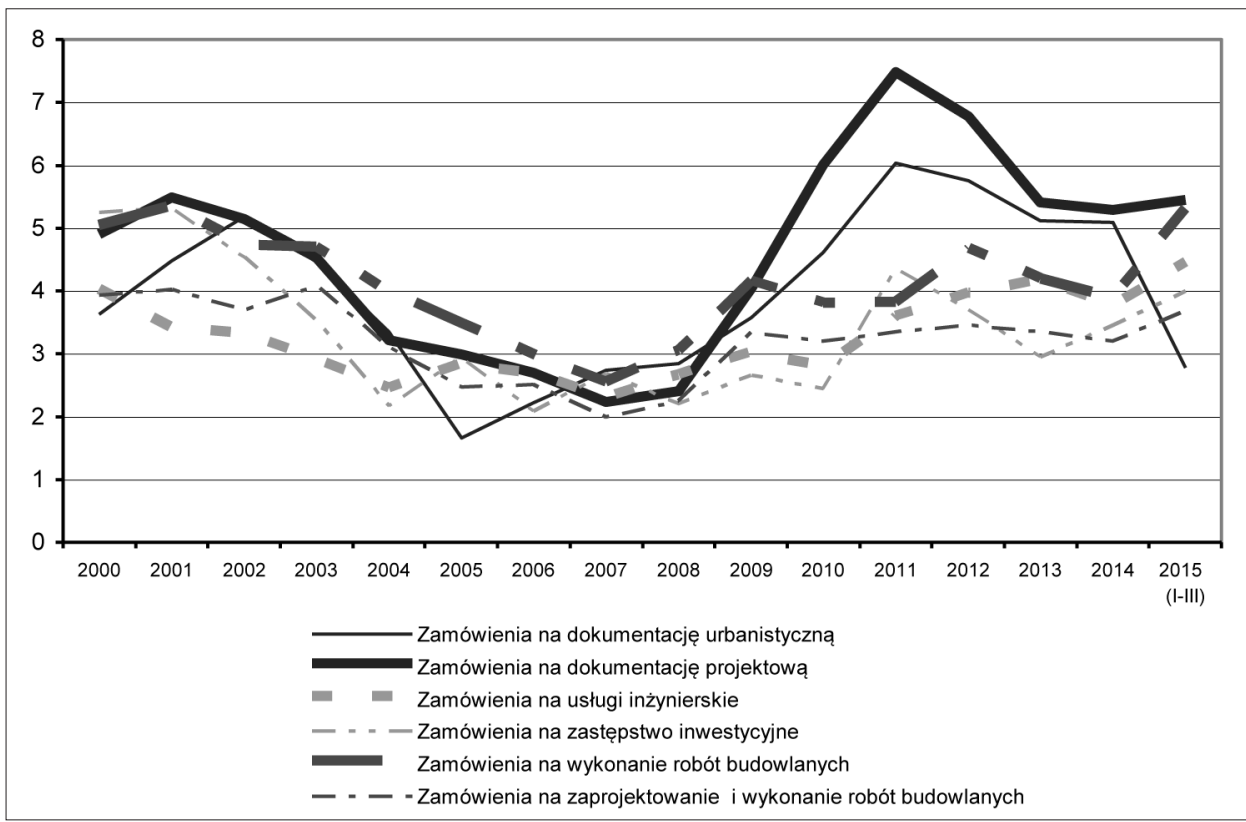

Wykres 2. Średnia liczba ofert na jedno postępowanie na badanych rynkach w latach 2000-2015 (I-III) Źródło: opracowanie własne na podstawie tabeli 2. 


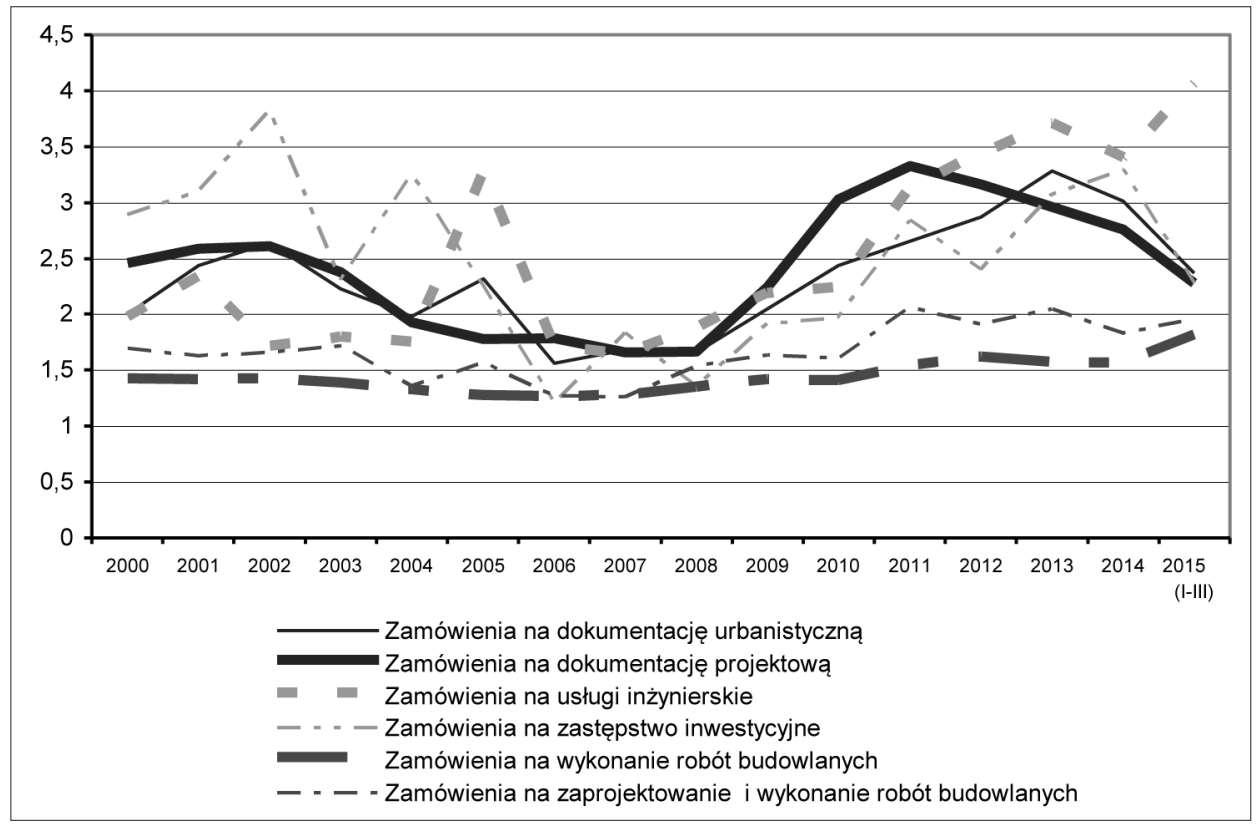

Wykres 3. Wskaźniki zróżnicowania cen ofertowych na badanych rynkach w latach 2000-2015 (I-III)

Źródło: opracowanie własne na podstawie tabeli 2.

Dane liczbowe zebrane w tabeli 2 pozwalają na skonstatowanie określonych prawidłowości. Na większości badanych rynków, w tym na szczególnie istotnych rynkach zamówień publicznych na prace projektowe i roboty budowlane, $w$ pierwszej połowie badanego okresu średnia liczba ofert składanych na jedno postępowanie systematycznie malała, podczas gdy w latach późniejszych nastąpiło wyraźne odwrócenie tego trendu, świadczące o nasilaniu się konkurencji oraz o rosnącym zainteresowaniu wykonawców polskim rynkiem zamówień publicznych pomimo formułowanych wobec niego, nie zawsze słusznie, zarzutów.

Dane z roku rozpoczynającego kolejną unijną perspektywę finansową (2014) oraz z I kwartału roku 2015 wskazują, iż opisana tendencja powinna zostać utrzymana. Jest to, generalnie rzecz biorąc, wniosek pozytywny. Świadczy on bowiem o wzroście zainteresowania podmiotów gospodarczych rynkiem zamówień publicznych.

Wskaźniki zróżnicowania cen ofertowych nie wykazują już tak wyraźnych tendencji. Średnie poziomy tych wskaźników w przypadku zamówień na usługi niematerialne związane $\mathrm{z}$ inwestowaniem budowlanym okazały się być niemal dwukrotnie wyższe niż w przypadku zamówień publicznych na roboty budowlane. Syntetycznym potwierdzeniem tej konstatacji są dane zamieszczone w tabeli 3. 


\begin{tabular}{|l|c|c|c|c|c|c|}
\hline \multirow{3}{*}{ Treść } & \multicolumn{2}{|c|}{$\begin{array}{c}\text { Zamówienia } \\
\text { na dokumentację }\end{array}$} & \multicolumn{2}{c|}{$\begin{array}{c}\text { Zamówienia } \\
\text { na usługi inżynierskie }\end{array}$} & \multicolumn{2}{c|}{$\begin{array}{c}\text { Zamówienia } \\
\text { na roboty budowlane }\end{array}$} \\
\cline { 2 - 7 } & $\begin{array}{c}\text { Dokumen- } \\
\text { tacja urba- } \\
\text { nistyczna }\end{array}$ & $\begin{array}{c}\text { Dokumen- } \\
\text { tacja pro- } \\
\text { jektowa }\end{array}$ & $\begin{array}{c}\text { Nadzory } \\
\text { inwestor- } \\
\text { skie }\end{array}$ & $\begin{array}{c}\text { Zastęp- } \\
\text { stwo inwe- } \\
\text { stycyjne }\end{array}$ & $\begin{array}{c}\text { Wykonanie } \\
\text { robót bu- } \\
\text { dowlanych }\end{array}$ & $\begin{array}{c}\text { Zaprojektowanie } \\
\text { i wykonanie robót } \\
\text { budowlanych }\end{array}$ \\
\hline $\begin{array}{l}\text { Wskaźnik } \\
\text { Wz }\end{array}$ & 2,76 & 2,86 & 3,13 & 2,59 & 1,57 & 1,97 \\
\hline
\end{tabular}

Tabela 3. Kształtowanie się wskaźników zróżnicowania cen $W_{z}$ w analizowanych zamówieniach publicznych w latach 2000-2015 (I-III) Źródło: obliczenia własne na podstawie tabeli 2.

Stwierdzone w wyniku badania statystycznego szerokie pasma dyspersji cen ofertowych na rynkach usług niematerialnych związanych z inwestycjami budowlanymi sugerują duże prawdopodobieństwo występowania na tych rynkach nieprawidłowości w zakresie konkurencji cenowej. Nieprawidłowości te mogą się wyrażać zarówno w częstym oferowaniu cen rażąco niskich lub dumpingowych, jak i w nadmiernym, czasem wręcz aberracyjnym zawyżaniu cen proponowanych w ofertach.

Stosunkowo wąskie pasmo rozrzutu cen ofertowych (57 punktów procentowych) stwierdzone w przypadku zamówień publicznych na wykonanie robót budowlanych również nie może zostać ocenione pozytywnie dlatego, że:

- jest ono zbyt szerokie wobec tradycyjnie ukształtowanego na polskim rynku budowlanym pasma o szerokości 40 punktów procentowych,

- relacje cen ofertowych do wartości zamówień kształtują się na rynku budowlanym w sposób nieprawidłowy. Tezę tę rozwiniemy i udokumentujemy w dalszej części publikacji.

\section{Problemy ilościowe}

\subsection{Niecenowe kryteria oceny ofert w obecnym stanie prawnym (po 19.10.2014 roku)}

Na skutek wejścia w życie w dniu 10.10.2014 roku jednej z uchwalonych ostatnio ustaw nowelizujących Pzp ${ }^{1}$, możliwości stosowania jednokryterialnego modelu oceny ofert (tylko cena) uległy znacznemu ograniczeniu. Dowartościowano zatem, przynajmniej formalnie, kryteria niecenowe.

1 Ustawa z 29.08.2014 roku o zmianie ustawy Prawo zamówień publicznych (Dz.U. z 2014 roku, poz. 1232). 
Zdaniem autora niniejszej publikacji, celowość takiego ograniczenia w odniesieniu do homogenicznych zamówień na wykonanie robót budowlanych jest wysoce dysksyjna. Niezależnie jednak od tych wątpliwości, uzasadnione jest postawienie pytania, w jakim stopniu kryteria niecenowe uległy na badanych rynkach faktycznemu dowartościowaniu w okresie obowiązywania zmienionych przepisów ustawy Pzp ${ }^{2}$. Dane liczbowe ilustrujące ten problem przedstawiono w tabeli 4 .

\begin{tabular}{|c|c|c|c|c|c|c|c|c|c|c|c|c|}
\hline \multirow{3}{*}{$\begin{array}{c}\text { Nazwa } \\
\text { kryte- } \\
\text { rium }\end{array}$} & \multicolumn{4}{|c|}{$\begin{array}{c}\text { Zamówienia } \\
\text { na dokumentację }\end{array}$} & \multicolumn{4}{|c|}{$\begin{array}{c}\text { Zamówienia } \\
\text { na usługi inżynierskie }\end{array}$} & \multicolumn{4}{|c|}{$\begin{array}{c}\text { Zamówienia } \\
\text { na roboty budowlane }\end{array}$} \\
\hline & \multicolumn{2}{|c|}{$\begin{array}{l}\text { Dokumenta- } \\
\text { cja urbani- } \\
\text { styczna }\end{array}$} & \multicolumn{2}{|c|}{$\begin{array}{c}\text { Dokumenta- } \\
\text { cja projek- } \\
\text { towa }\end{array}$} & \multicolumn{2}{|c|}{$\begin{array}{l}\text { Nadzory in- } \\
\text { westorskie }\end{array}$} & \multicolumn{2}{|c|}{$\begin{array}{l}\text { Zastępstwo } \\
\text { inwestycyjne }\end{array}$} & \multicolumn{2}{|c|}{$\begin{array}{l}\text { Wykonanie } \\
\text { robót bu- } \\
\text { dowlanych }\end{array}$} & \multicolumn{2}{|c|}{$\begin{array}{l}\text { Zaprojekto- } \\
\text { wanie } \\
\text { i wykonanie } \\
\text { robót bu- } \\
\text { dowlanych }\end{array}$} \\
\hline & $a$ & $b$ & $a$ & $b$ & $a$ & $b$ & $a$ & $b$ & $a$ & $b$ & $a$ & $b$ \\
\hline Cena & 100,00 & 91,76 & 100,00 & 92,82 & 100,00 & 94,79 & 100,00 & 91,76 & 100,00 & 92,29 & 100,00 & 89,92 \\
\hline $\begin{array}{c}\text { Warunki } \\
\text { płatno- } \\
\text { ści }\end{array}$ & - & - & - & - & - & - & - & - & 0,05 & 6,88 & - & \\
\hline $\begin{array}{c}\text { Wiary- } \\
\text { godność } \\
\text { oferenta }\end{array}$ & 5,88 & 12,00 & - & - & 2,79 & 6,44 & 6,67 & 10,00 & 0,12 & 10,00 & 0,22 & 20,00 \\
\hline \begin{tabular}{|c|} 
Sposób \\
wyko- \\
nania \\
zamó- \\
wienia \\
\end{tabular} & 1,18 & 40,00 & - & - & 0,31 & 2,00 & - & - & 0,28 & 10,12 & 0,67 & 10,00 \\
\hline Termin & 23,53 & 9,65 & 43,33 & 11,00 & 0,31 & 4,00 & - & - & 13,54 & 10,49 & 23,11 & 11,94 \\
\hline $\begin{array}{c}\text { Warunki } \\
\text { gwa- } \\
\text { rancji/ } \\
\text { rękojmi }\end{array}$ & 3,53 & 8,66 & 10,00 & 8,33 & 10,19 & 8,75 & 6,67 & 10,00 & 55,79 & 8,23 & 50,00 & 8,74 \\
\hline $\begin{array}{c}\text { Inne } \\
\text { kryteria }\end{array}$ & 31,76 & 13,29 & 20,00 & 6,66 & 55,56 & 7,17 & 60,00 & 9,66 & 12,98 & 11,18 & 13,11 & 13,23 \\
\hline
\end{tabular}

Tabela 4. Istotność poszczególnych kryteriów oceny ofert w zamówieniach związanych z inwestycjami budowlanymi w okresie od X 2014 do VI 2015 a = wskaźnik popularności kryterium, obliczony jako iloraz postępowań w którym dane kryterium zostało zastosowane do wszystkich postępowań danego rodzaju ogłoszonych w BZP w okresie objętym badaniem; $\mathrm{b}=$ średnia waga kryterium w okresie objętym badaniem. Źródło: obliczenia własne na podstawie BZP.

2 Mowa tutaj o art. 91 ust. 2 i 2 a Pzp. 
Dane przedstawione w tabeli 4 sygnalizują kolejny, dość istotny problem, z jakim mamy do czynienia na rynkach zamówień publicznych związanych $\mathrm{z}$ procesem inwestycyjno-budowlanym. Problemem tym jest pozorne tylko, a nie faktyczne, dowartościowanie niecenowych kryteriów oceny ofert. Najbardziej przekonującymi wskaźnikami, które ten problem sygnalizują, są uśrednione wskaźniki wagowe przypisywane na poszczególnych rynkach objętych badaniem cenie jako kryterium oceny ofert. W pięciu przypadkach były one wyższe niż $90 \%$ natomiast na szóstym rynku (zaprojektowanie i wykonanie robót budowlanych) wskaźnik ten wyniósł blisko 90\% (89,92\%).

$\mathrm{Na}$ tym tle fakt, iż wskaźniki popularności pewnych kryteriów niecenowych na niektórych rynkach były wysokie, ma już znaczenie drugoplanowe. Oznacza on bowiem jedynie, iż jakkolwiek stosowanie wielokryterialnego modelu oceny ofert zostało wymuszone przez zmienione przepisy Pzp, to jednak zamawiający wykonują $\mathrm{w}$ tym zakresie jedynie ruchy pozorne. Kryterium, które w sposób zdecydowany decyduje o wyborze najkorzystniejszej oferty nadal bowiem pozostaje cena.

Konstatacja ta prowadzi z kolei do wniosku dalej idącego. Mówi on, iż normy prawne nie są omnipotentne. Tak więc, chcąc zrealizować określony cel, na przykład w zakresie systemu zamówień publicznych, właściwe podmioty powinny zastosować, oprócz legislacyjnych, również inne instrumenty oddziaływania na interesariuszy systemu.

\subsection{Nieracjonalne relacje cen ofertowych do wartości zamówień}

Badania statystyczne relacji cen ofertowych do wartości zamówień stały się możliwe do prowadzenia od momentu wejścia w życie aktualnie obowiązującego rozporządzenia $\mathrm{w}$ sprawie wzorów ogłoszeń zamieszczonych w Biuletynie Zamówień Publicznych ${ }^{3}$. Rozporządzenie to, w załączniku 4, zawiera jednolity i obligatoryjny wzór ogłoszenia o udzieleniu zamówienia publicznego. Punkty IV.5 i IV.6 tego wzoru nakazują natomiast zamawiającemu opublikowanie, niezwłocznie po zawarciu umowy, informacji zarówno o szacunkowej wartości zamówienia jak i o cenach oferty wybranej oraz ofert z najniższą i najwyższą ceną ${ }^{4}$.

Czynniki obiektywne które mogą ograniczać wartość poznawczą takiego badania wynikają z tego, że:

- wartość zamówienia publicznego nie obejmuje podatku VAT, natomiast cena podatek VAT uwzględnia,

3 Mowa tu o rozporządzeniu Prezesa Rady Ministrów z 28.01.2010 roku w sprawie wzorów ogłoszeń zamieszczanych w Biuletynie Zamówień Publicznych (Dz.U. Nr 12 z 2010 roku, poz. 69 ze zmianami).

4 Por. również art. 95 ust. 1 i 2 ustawy Pzp. 
- w przypadku, gdy zamawiający przewiduje udzielenie zamówień uzupełniających, przepis art. 32 ust. 1 pkt 3 Pzp nakazuje mu uwzględnić przy ustalaniu wartości zamówienia również wartość zamówień uzupełniających.

Postanowiono zatem w autorskich programach informatycznych, zastosowanych do relacjonowanych w niniejszej publikacji obliczeń, wprowadzić odpowiednie korekty. Korekty te umożliwiły:

- uwzględnienie w obliczeniach relacji cen ofertowych do wartości tylko w tych postępowaniach, w których zamówienia uzupełniające nie były przewidywane oraz

- powiększenie podawanych w BZP wartości zamówień o stawkę VAT, która w przypadku robót budowlanych wynosi zwykle 23\%.

Relacje cen do wartości obliczono według wzoru:

$$
A_{X}=\frac{\sum_{i=1}^{n} \frac{C_{w y b . i}}{1,23 \times W_{i}}}{n}
$$

gdzie:

$A_{X}$ - wskaźnik ilustrujący uśrednioną relację cen wybranych ofert do wartości zamówień wybieranych należących do zbioru $X$,

$C_{w y b . i}$ - cena oferty wybranej w postępowaniu $i$-tym,

$1,23 \times W i$ - szacunkowa wartość zamówienia w postępowaniu $i$-tym powiększona o podatek VAT (23\%),

$n$ - liczba zamówień należących do zbioru $X$.

Wyniki dokonanych obliczeń przedstawiamy w tabeli 5.

\begin{tabular}{|c|c|c|c|c|c|c|c|c|c|}
\hline \multirow[b]{2}{*}{ Rok } & \multirow{2}{*}{$\begin{array}{c}\text { Zamówienia na } \\
\text { wykonanie robót } \\
\text { budowlanych (45.00) }\end{array}$} & \multicolumn{8}{|c|}{ W tym klasy CPV: } \\
\hline & & 45.10 & 45.21 & 45.22 & 45.23 & 45.24 & 45.26 & 45.30 & 45.40 \\
\hline 2010 & 0,724 & 0,732 & 0,740 & 0,769 & 0,731 & 0,709 & 0,710 & 0,712 & 0,721 \\
\hline 2011 & 0,755 & 0,741 & 0,777 & 0,816 & 0,754 & 0,758 & 0,751 & 0,735 & 0,777 \\
\hline 2012 & 0,731 & 0,713 & 0,769 & 0,759 & 0,719 & 0,673 & 0,737 & 0,736 & 0,745 \\
\hline 2013 & 0,751 & 0,755 & 0,782 & 0,791 & 0,743 & 0,674 & 0,763 & 0,766 & 0,773 \\
\hline 2014 & 0,775 & 0,774 & 0,801 & 0,808 & 0,770 & 0,678 & 0,749 & 0,774 & 0,789 \\
\hline $2015(\mathrm{I}-\mathrm{VI})$ & 0,731 & 0,716 & 0,769 & 0,751 & 0,697 & 0,747 & 0,750 & 0,746 & 0,776 \\
\hline Ogółem & 0,746 & 0,743 & 0,770 & 0,786 & 0,741 & 0,707 & 0,740 & 0,742 & 0,760 \\
\hline
\end{tabular}

Tabela 5. Relacje cen wybieranych ofert do wartości na rynkach budowlanych zamówień publicznych w latach 2010-2015 (I-VI) Źródło: obliczenia własne na podstawie BZP. 
Jak wynika $\mathrm{z}$ danych zamieszczonych $\mathrm{w}$ tabeli, $\mathrm{w}$ całym badanym okresie zarówno na rynku zamówień publicznych na wykonanie robót budowlanych, jak i w jego poszczególnych segmentach (klasach CPV) ceny wybieranych ofert były średnio biorąc, niższe od „ubruttowionej” wartości zamówien.

Wcześniejsze badania autora niniejszego referatu wskazują na fakt, iż omawiane relacje w sposób równie nieracjonalny kształtują się również na innych rynkach zamówień udzielanych $\mathrm{w}$ ramach procesu inwestycyjnego ${ }^{5}$.

Stwierdzony w wyniku przeprowadzonych badań fakt nieracjonalnego kształtowania się cen do wartości uznać należy za sygnał istotnego spatologizowania zachowań cenotwórczych zarówno zamawiających odpowiedzialnych za szacowanie $\mathrm{z}$ należytą starannością wartości zamówień, jak i wykonawców kalkulujących ceny ofertowe. Jedną z konsekwencji wspomnianej patologizacji jest natomiast wątpliwa wiarygodność obliczeń próbujących określić efektywność danego zamówienia.

Problem niedostatecznej wiarygodności zachowań kalkulacyjnych interesariuszy polskiego systemu zamówień publicznych jest tym istotniejszy, że nowe zamówieniowo-publiczne dyrektywy UE, a w ślad za nimi nowa polska ustawa Pzp, przewidują powszechne stosowanie na rynku zamówień publicznych rachunku kosztów cyklu życia przedmiotu zamówienia. Rachunek ten natomiast stawia swoim kalkulatorom znacznie dalej idące wymagania niż „klasyczna” kalkulacja cen ofertowych i wartości zamówień.

\section{Problemy jakościowe}

\subsection{Niedostateczny profesjonalizm zachowań cenotwórczych zamawiających i wykonawców na przykładzie robót budowlanych}

Niedostateczna wiarygodność kosztorysowania inwestorskiego w zamówieniach publicznych jest efektem zarówno przesłanek wynikających z przeszłości jak i powodów o aktualnym charakterze.

5 A. Borowicz, Zamówienia publiczne w procesie inwestycyjno-budowlanym: tendencje i zagrożenia, [w:] Prawo zamówień publicznych. Stan obecny i kierunki zmian, red. H. Nowicki, P. Nowicki, Wrocław 2015, s. 135-151. 
Przesłanki historyczne związane są z przedwczesną deregulacją kosztorysowania budowlanego $\mathrm{w}$ Polsce ${ }^{6}$. Wśród przesłanek aktualnych wskazać można na brak zainteresowania zamawiających wysoką jakością kosztorysów oraz niewłaściwe rozwiązania zastosowane w ustawie Pzp w odniesieniu do kategorii rażąco niskiej ceny.

Niezależnie od wyżej wymienionych czynników zewnętrznych, na niski poziom kosztorysów inwestorskich w zamówieniach publicznych wpływ mają również czynniki o charakterze endogenicznym, immanentnie związane z samą istotą kosztorysowania budowlanego ${ }^{7}$.

W warunkach pełnej deregulacji budowlanego kosztorysowania ofertowego w naszym kraju, jedyną systemową możliwość oddziaływania na poziom tych opracowań daje przywołany w tytule punktu przepis ustawy Pzp. Przypomnijmy zatem, iż przepis ten nakazuje zamawiającemu określić w SIWZ, wymagany od wszystkich wykonawców biorących udział w danym postępowaniu, sposób obliczania (i wyrażenia w ofercie) oferowanej ceny.

W efekcie oddziaływania takich cech specyficznych budownictwa jak indywidualny charakter oraz złożoność i nieruchomość produktu budowlanego, a także długi cykl produkcyjny, kalkulacja kosztów i cen $\mathrm{w}$ tym dziale produkcji jest procesem skomplikowanym. A zatem wykorzystanie przez zamawiających możliwości, jakie wynikają z przywołanego przepisu Pzp ma bardzo istotne znaczenie dla jakości kosztorysów ofertowych. Zamawiający powinien w omawianym zapisie SIWZ odpowiedzieć na około 10 szczegółowych pytań dotyczących sposobu kalkulowania i przedstawienia $\mathrm{w}$ ofercie proponowanej przez każdego $\mathrm{z}$ wykonawców ceny budowlanej.

Zarówno systematyczne badania przeprowadzone dwukrotnie przez autora niniejszej publikacji ${ }^{8}$, jak i bieżący monitoring omawianego zagadnienia prowadzą do wniosku, iż zamawiający wciąż w sposób niedostateczny wykorzystują możliwości jakie daje im art. 36 ust. 1 pkt 12 Pzp. Konsekwencją tego faktu jest natomiast zarówno obniżenie jakości i porównywalności kalkulacji cen ofertowych, jak i spory arbitrażowe oraz sądowe wszczynane na tym tle.

6 Deregulacja ta stanowiła bezpośrednią konsekwencję wejścia w życie w dniu 12.12.2001 roku ustawy z 25.07.2001 roku o cenach (Dz.U. Nr 97, poz. 1050).

7 Szerzej na ten temat patrz: A. Borowicz, Wiarygodność kosztorysu inwestorskiego, „Prawo Zamówień Publicznych” 2014, nr 1, s. 3-11 oraz A. Borowicz, A. Warwas, Profesjonalizacja kosztorysowania inwestorskiego w zamówieniach publicznych, artykuł przyjęty do druku w kwartalniku naukowym „Prawo Zamówień Publicznych”.

$8 \mathrm{Na}$ temat wyników tych badań patrz: A. Borowicz, Sposób obliczania cen ofertowych w świetle zapisów SIWZ, [w:] Inwestycje budowlane w sektorze publicznym aktualne uwarunkowania i aspekty praktyczne. XII konferencja naukowo-techniczna, Ciechocinek 19-20 października 2006 r., Warszawa 2006, s. 101-121; A. Borowicz, Jak obliczyć cenę oferty w zamówieniach publicznych, Ciechocinek 2011, materiały konferencyjne, s. 9-21. 


\subsection{Rozwiązania projektowanej ustawy Pzp dedykowane zamówieniom publicznym na roboty budowlane}

Analizując rozwiązania dedykowane zamówieniom budowlanym, jakie wynikają z projektu Prawa zamówień publicznych z dnia 17.04.2015 r., można dostrzec $\mathrm{w}$ niektórych $\mathrm{z}$ nich potencjalne źródło problemów w procesie inwestycyjno-budowlanym. Uwaga ta odnosi się w pierwszym rzędzie do normatywnych wymagań stawianych opisowi przedmiotu zamówienia na roboty budowlane.

Przypomnijmy zatem, że w aktualnie obowiązującej ustawie Pzp spo- $^{9}$ sób dokumentacyjnego doprecyzowania opisu przedmiotu zamówienia na roboty budowlane sformułowany był koherentnie, zarówno w treści samej ustawy (art. 31) jak również w wydanym na jej podstawie rozporządzeniu wykonawczym ${ }^{10}$. W projekcie nowej ustawy Pzp omawiany problem uwzględniony został jedynie w samym jej tekście. Mamy tu na myśli zwłaszcza art. 61 ust. 2 i 3. Pierwszy z tych przepisów nakazuje zamawiającemu określić w opisie przedmiotu budowlanego zamówienia publicznego wymagane cechy materiału, produktu lub dostawy, odpowiadające przeznaczeniu udzielanego zamówienia. Z punktu widzenia istoty oraz specyfiki procesu budowlanego przepis ten jest, zdaniem autora niniejszej publikacji, mało istotny i nieprecyzyjny. Drugi z przywołanych przepisów (ust. 3) ma charakter enumeracji, która jednak ma być stosowana jedynie warunkowo i fakultatywnie („zamawiający może w miarę możliwości wymagać w szczególności...”). Wspomniana enumeracja wyszczególnia podstawowe elementy opisu przedmiotu zamówienia na roboty budowlane. Dodać należy, że niektóre z tych elementów adekwatne są do homogenicznych zamówień na wykonanie robót budowlanych, natomiast inne odzwierciedlają specyfikę łącznych zamówień na zaprojektowanie i wykonanie robót budowlanych.

Jak widać, autorzy projektu ustawy zrezygnowali z wymogu doprecyzowania opisu przedmiotu budowlanego zamówienia publicznego za pomocą konkretnych, nazwanych opracowań projektowo-inżynierskich o, również narzuconej przepisami, minimalnej treści. Ażeby uświadomić sobie ryzyko wynikające $\mathrm{z}$ przyjętego w projekcie ustawy rozwiązania, należy wskazać na fakt, iż w rezultacie zasadniczych zmian systemowych (tzw. plan Balcerowicza) polski rynek budowlany został w znacznym stopniu zderegulowany. Podejmując stosowne decyzje deregulacyjne,

9 Dz.U. Nr 19 z 2014 roku, poz. 177 ze zm.

10 Mamy tu na myśli rozporządzenie Ministra Infrastruktury z dnia 2.09.2004 roku w sprawie szczegółowego zakresu i formy dokumentacji projektowej, specyfikacji technicznych wykonania i odbioru robót budowlanych oraz programu funkcjonalno-użytkowego (Dz.U. Nr 202, poz. 2072). 
nie wzięto jednak pod uwagę specyfiki procesu inwestycyjno-budowanego. Mamy tu na myśli głównie fakt, iż w procesie tym wielkie znaczenie mają decyzje i opracowania podejmowane / sporządzane w fazach przedprojektowych, natomiast sama dokumentacja projektowa powinna powstawać metodą kolejnych iteracji. Rozwiązania dotychczas obowiązujące specyfikę tę w znacznym stopniu uwzględniały. Przykładem może tu być wymóg sporządzania wytycznych do zaprojektowania inwestycji budowlanej (PFU) ${ }^{11}$ oraz wymóg opracowania, tam gdzie to jest niezbędne, oprócz projektu budowlanego, również projektu realizacyjnego.

Pominięcie w projekcie nowego Pzp opisanych wymagań dokumentacyjnych pociąga za sobą również ryzyko dalszego obniżenia się merytorycznej jakości opracowań projektowych w polskim sektorze publicznych inwestycji budowlanych. Ryzyko to jest tym większe, że dotychczasowy poziom projektowania budowlanego w tym sektorze już pozostawiał bardzo wiele do życzenia.

\section{Bibliografia}

Borowicz A., Sposób obliczania cen ofertowych w świetle zapisów SIWZ, [w:] Inwestycje budowlane w sektorze publicznym - aktualne uwarunkowania i aspekty praktyczne. XII konferencja naukowo-techniczna, Ciechocinek 19-20 października 2006 r., Warszawa 2006.

Borowicz A., Jak obliczyć cenę oferty w zamówieniach publicznych, Ciechocinek 2011.

Borowicz A., Wiarygodność kosztorysu inwestorskiego, „Prawo Zamówień Publicznych” 2014, nr 1.
Borowicz A., Zamówienia publiczne $w$ procesie inwestycyjno-budowlanym: tendencje i zagrożenia, [w:] Prawo zamówień publicznych. Stan obecny i kierunki zmian, red. H. Nowicki, P. Nowicki, Wrocław 2015.

Borowicz A., Warwas A., Profesjonalizacja kosztorysowania inwestorskiego w zamówieniach publicznych, artykuł przyjęty do druku w kwartalniku naukowym „Prawo Zamówień Publicznych”.

11 Na podkreślenie zasługuje fakt, iż PFU stosowany był powszechnie nie tylko w zamówieniach na zaprojektowanie i wykonanie robót budowlanych, ale również w zamówieniach wyłącznie na prace projektowe. Mieliśmy tu zatem do czynienia z tzw. efektem demonstracji. Środowiska profesjonalne uznały bowiem praktyczną przydatność swoistego wzorca wytycznych do projektowania jakim de facto jest PFU i stosowały to opracowanie również w tych przypadkach w których nie było to wymagane przez ustawę Pzp. 